\title{
Streptococcus pneumoniae Serotype 10A IgG Antibody Measurement
}

National Cancer Institute

\section{Source}

National Cancer Institute. Streptococcus pneumoniae Serotype $10 \mathrm{~A}$ Ig G Antibody

Measurement. NCI Thesaurus. Code C142259.

The determination of the amount of Streptococcus pneumoniae serotype 10A Ig G antibody present in a sample. 